PRZEGLĄD NAUK HISTORYCZNYCH 2020, R. XIX, NR 1

http://dx.doi.org/10.18778/1644-857X.19.01.07

\title{
Powieści historyczne Antoniny Domańskiej w przekazie literackim, audiowizualnym, cyfrowym i teatralnym
}

Streszczenie. Krakowska pisarka Antonina Domańska (1853-1917) zajmuje trwałe miejsce w polskiej tradycji kulturalnej jako autorka utworów literackich dla dzieci i młodzieży, głównie powieści historycznych. Jej najbardziej znane książki to Paziowie króla Zygmunta (1910) i Historia żółtej ciżemki (1913). Powieści te doczekały się adaptacji, pierwsza - filmowej Sylwestra Chęcińskiego (1961), druga - serialowej Grzegorza Warchoła (1989). W polskich teatrach były również wystawiane przeróbki sceniczne Historii żółtej ciżemki. Tematem artykułu jest obraz Krakowa w tych powieściach jako kluczowy element edukacji historyczno-patriotycznej A. Domańskiej. Drugie zagadnienie badawcze stanowi recepcja filmowa, telewizyjna oraz teatralna dwóch utworów pisarki.

Słowa kluczowe: Domańska Antonina (1853-1917), powieść historyczna dla dzieci, film polski po 1945 - historia; teatr polski po 1945 - historia.

ntonina Domańska (1853-1917) jest znana jako autorka
utworów literackich, przede wszystkim powieści historycz-
nych, dla dzieci i młodzieży. Szczególnie jej Paziowie króla Zygmunta (1910) i Historia żółtej ciżemki (1913) są ważną częścią ojczystego kanonu literackiego. Pisarka odegrała ważna rolę w zakresie edukacji historycznej i wychowania patriotycznego, ponieważ popularyzowała wśród dziecięcych odbiorców w czasach zaborów wiedzę o przedrozbiorowych dziejach Polski. Interesowały ja też szerzej pojęta praca wychowawcza i działalność opiekuńcza, czemu

* Wydział Socjologiczno-Historyczny, Instytut Historii, Zakład Kulturoznawstwa, e-mail: adrianuljasz5@wp.pl 
dała wyraz, współpracując jako społeczniczka $z$ tzw. instytucjami opieki na dziećmi ${ }^{1}$. Powieści historyczne A. Domańskiej spotykaja się z zainteresowaniem czytelniczym nie tylko ze strony dzieci, lecz także dorosłych odbiorców literatury ${ }^{2}$.

Autorka, propagując „przeszłość narodowa”3, czyniła miejscem akcji literackiej przede wszystkim swoje miasto - Kraków. Dzięki temu młodzi czytelnicy, żyjący w kraju podzielonym przez zaborców, a później niepodległym, mocniej utożsamiali się $z$ dawną stolicą Rzeczpospolitej oraz krakowską i zarazem ogólnopolską spuścizną kulturową. Uczyli się patriotyzmu, co podkreślano w publikacjach poświęconych pisarce ogłoszonych jeszcze przed 1918 r. ${ }^{4}$

Najważniejsze obiekty historyczno-kulturowe, należace do tradycji krakowskiej i jednocześnie narodowej, stanowią Wawel oraz kościół Mariacki z ołtarzem Wita Stwosza. Dotyczą ich dwie najbardziej znane ksiaż̇ki A. Domańskiej - Paziowie króla Zygmunta i Historia żółtej ciżemki. Oba zabytki znajduja się wśród podstaw ojczystego „residuum tradycji”. Utwory te doczekały się adaptacji:

1 Z. Ciechanowska, Domańska z Kremerów Antonina (1853-1917), [w:] Polski słownik biograficzny, t. V, z. 1, Kraków 1939, s. 299; E.G. [E. Głębicka], Domańska Antonina 1853-1917, [w:] Współcześni polscy pisarze i badacze literatury. Słownik biobliograficzny, red. J. Czachowska, A. Szałagan, t. II $(C-F)$, Warszawa 1994, s. 189; Domańska Antonina (1853-1917), [w:] Słownik współczesnych pisarzy polskich, red. E. Korzeniewska, t. I (a-i), Warszawa 1963, s. 443-444; KK [K. Kuliczkowska], Domańska Antonina ur. IX 1853 w Kamieńcu, zm. 26 I 1917 w Krakowie, [w:] Nowy słownik literatury dla dzieci i młodzieży. Pisarze. Ksią̇ki. Serie. Ilustratorzy. Przeglad bibliograficzny, Warszawa 1979, s. 140-141; MZS [M. Ziółkows ka-S obecka], Domańska Antonina, [w:] S. Frycie, M. Ziółkowska-Sobecka, Leksykon literatury dla dzieci $i$ młodzieży, Piotrków Trybunalski 1999, s. 77.

2 S. Dzie dzic, Pani radczyni-Antonina Domańska, „Dialog Dwóch Kultur” 2017, R. XII, z. 1, s. 278.

${ }^{3}$ Określenie Marka Kątnego, por. idem, Antonina Domańska. Propagator przeszłości narodowej, „Studia Słowianoznawcze” 2006, R. VI, s. 21-40.

${ }^{4}$ Por. np. Antonina Domańska, „Kobieta Polska” 1917, R. II, nr 3, s. 8 (notatka pośmiertna o A. Domańskiej). Autorzy publikacji prasowych zwracali także uwage na zrozumienie pisarki dla dzieci, na cechujaca ja znajomość dziecięcej psychiki. Por. as [T. Sin ko], Poetka lalek i dzieci. Śp. Antonina Domańska, "Czas” 1917, R. LXX, nr 53, s. 1. O empatycznym stosunku do dzieci może świadczyć wspomnienie $z$ dzieciństwa autorstwa Stanisława Arcta, który był synem jednego z najważniejszych wydawców twórczości A. Domańskiej - Michała Arcta: „Lubiłem bardzo pania Antoninę Domańska [...]. Domańska, dość tęga blondynka, gładko zaczesana, miała zawsze jakieś przyjemne słówko dla mnie i była taka bardzo swojska”. S. Arct, Okruchy wspomnień, Warszawa 1962, s. 167.

${ }^{5}$ Określenie zastosowane w liczbie mnogiej - „residua tradycji” przez literaturoznawcę Ewę Kos owską. Por. eadem, Porady (?) radczyni. O powieściach historycznych Antoniny Domańskiej, „Guliwer” 2012, R. XXII, nr 1, s. 43. 
pierwszy w formie bardzo popularnego filmu Sylwestra Chęcińskiego (1961), a drugi serialu telewizyjnego Grzegorza Warchoła (1989). Przeróbki sceniczne Historii żółtej ciżemki były również wystawiane na deskach polskich teatrów. Tematem artykułu jest obraz Krakowa w tych powieściach jako kluczowy element edukacji historyczno-patriotycznej prowadzonej przez A. Domańska za pomoca jej twórczości literackiej. Podjęte zostanie również zagadnienie recepcji filmowej, telewizyjnej oraz teatralnej dwóch utworów pisarki.

Akcja Paziów króla Zygmunta (pierwodruk: 1910 r.) toczy się na zamku wawelskim, na dworze króla Zygmunta Starego. Czytelnicy poznaja Wawel jako symbol polskiej tradycji narodowohistorycznej. Śledząc przed 1918 r. przygody młodzieżowych bohaterów ${ }^{6}$, rozgrywające się na terenie zabytku narodowego, umacniali w sobie ponadzaborowe poczucie jedności etnicznej, historycznej i kulturowej. Jednocześnie Wzgórze Wawelskie i Wawel stawały się w ich świadomości podstawowym elementem obrazu Krakowa.

Autorka przekazała w powieści bardzo ważne wiadomości $z$ ojczystej historii kultury i z dziejów politycznych dawnej Polski. Omówiła sprawę przebudowy Wawelu na modłę renesansowa za panowania Zygmunta Starego i królowej Bony. Popularyzowała postać projektanta przeróbki - architekta i rzeźbiarza Bartolomea Berecciego. Pisała $z$ żalem o gotyckiej części Wawelu, „skazanej na zburzenie"7. Inne postaci historyczne związane $z$ Wawelem, jako krakowskim zabytkiem, pokazane przez A. Domańska to Zygmunt Stary, królowa Bona, błazen Stańczyk, biskup krakowski Piotr Tomicki, biskup Andrzej Krzycki, hetmani Jan Tarnowski i Mikołaj Firlej, marszałek Piotr Kmita z Wiśnicza.

W Paziach króla Zygmunta pisarka upowszechniała także wiedzę o dziejach polskiego drukarstwa, piszac o Żywocie Pana Jezu Krista, przetłumaczonym ze św. Bonawentury przez Baltazara Opecia, opublikowanym w 1522 r. przez krakowską drukarnię Jana Hallera. W powieściowym obrazie Krakowa nie zabrakło informacji o Akademii Krakowskiej jako o polskiej uczelni, mającej wśród absolwentów Mikołaja Kopernika8.

\footnotetext{
${ }^{6}$ A. Do mańska, Paziowie króla Zygmunta, oprac. graficzne J.S. Miklaszewski, Warszawa 1962, passim.

7 Ibidem, s. 145 (tu także cytat przywołany wyżej).

8 Ibidem, passim. Badaczka dziejów polskiej powieści historycznej dla dzieci i młodzieży Gertruda Skotnicka trafnie stwierdziła na temat dzieł literackich z okresu Młodej Polski dotyczących czasów Jagiellonów: „Wiele miejsca poświęcono osiagnięciom kultury, sztuki i nauki, szczególnie w utworach A. Domańskiej”.
} 
Do dziejów kultury należy też powieszenie i poświęcenie dzwonu Zygmunt na wieży zygmuntowskiej w katedrze wawelskiej. Autorka, opisując uroczystość towarzysząca temu wydarzeniu, ukazuje $\mathrm{w}$ tle scenerię i topografię krakowską. Wymienia m.in. istniejący do dziś klasztor Franciszkanów i jedna $z$ dwóch wież mariackich stojących przy kościele Mariackim. O poczuciu odpowiedzialności autorki jako pisarki-edukatorki świadczy przypis, jaki dodała do tekstu literackiego, piszac o dzwonie Zygmunt: „Dzwon "Zygmunt" odlany był w r. 1520. Ze względu na piękność tej chwili, przesunęłam datę, byle umieścić ten epizod w moim opowiadaniu" ${ }^{9}$. Zasygnalizowana postawa pisarki pozwala uznać jej powieść za przykład nie tylko edukacji historycznej, lecz także pozaszkolnej literackiej działalności dydaktycznej. Przykład pisarskiego nastawienia dydaktycznego to także podanie informacji źródłowej - powołanie się na Kronike polska Marcina Bielskiego w opisie ataku niedźwiedzia na królową Bonę, jadąca na koniu podczas polowania w Puszczy Niepołomickiej. Wartość edukacyjną powieści A. Domańskiej, m.in. Paziów króla Zygmunta, powiększały zwartość struktury fabuły i stosunkowo nieduża objętość tekstu ${ }^{10}$. W powieści z 1910 r. pisarka uczyła, bawiąc, ponieważ zrębem fabuły uczyniła kolejne figle królewskich paziów na wawelskim dworze ${ }^{11}$.

Na skuteczność przekazu edukacyjnego utworów A. Domańskiej, w tym książki o paziach, w dużym stopniu wpływały literackie umiejętności narracyjne pisarki. Dyrektor Muzeum Historycznego Miasta Krakowa Michał Niezabitowski stwierdził na ten temat w wywiadzie z 2017 r. dla miesięcznika „Kraków”, że „autorka miała niezwykły dar narracyjny, wiedzę historyczną i niesamowita wyobraźnię. Domańska jest bliska nam, muzealnikom, bo dzisiaj muzealnik musi mieć ten dar opowiadania. [...] Wydaje mi się, że powodem aktualnego boomu muzealnego (30 mln zwiedza-

G. Skotnicka, Dzieje piórem malowane. O powieściach historycznych dla dzieci i młodzieży z okresu Młodej Polski i dwudziestolecia międzywojennego, Gdańsk 1987, s. 129.

9 A. Domańska, op. cit., s. 95.

${ }_{10}$ G. Skotnicka, Tradycje narodowo-kulturowe $w$ polskiej powieści historycznej dla dzieci i młodzieży, [w:] Tradycje narodowo-kulturowe w literaturze dla dzieci i młodzieży. Materiały z sesji Jachranka, 30 XI- 2 XII 1994 r., Warszawa 1996, s. 48.

11 A. Domańska, op. cit., passim; K. Kuliczkowska, Literatura dla dzieci i młodzieży, [w:] Literatura okresu Młodej Polski, t. III, red. K. Wyka, A. Hutnikiewicz, M. Puchalska, Kraków 1973, s. 576. 
jących odnotowały polskie muzea w 2015 r.) jest fakt, że muzea nauczyły się wreszcie ciekawie opowiadać, a nie tylko statystycznie wystawiać"12.

W Paziach króla Zygmunta zostało ukazane niezmiernie ważne wydarzenie $z$ dziejów polskiej polityki zagranicznej - złożenie hołdu pruskiego w 1525 r. w Krakowie przez księcia Albrechta. Przy opisie krakowskich uroczystości towarzyszacych temu aktowi pojawia się wzmianka o ulicy Grodzkiej oraz równie ważnej, jak Wawel, ikonie kulturowej związanej z Krakowem - hejnale mariackim.

Słabą stronę powieści stanowi utrwalanie stereotypów historycznych, szczególnie negatywnego wizerunku królowej Bony. Inna słabość utworu to poparcie pisarki dla szesnastowiecznych prześladowań polskich protestantów. Czytelnicy, zapoznając się z takim stanowiskiem, mogli się uczyć nietolerancji wyznaniowej.

Paziowie króla Zygmunta otrzymywali na przestrzeni lat wysokie oceny od popularyzatorów literatury dla dzieci i młodzieży oraz od publicystów. Powieść dostała pochwałę np. w książkowym katalogu wydawnictw zwartych, opublikowanym 1912 r., adresowanym do bibliotekarzy. Anonimowy autor docenił książkę za walory rozrywkowe oraz rzetelny przekaz wiedzy historycznej ${ }^{13}$. W $1931 \mathrm{r}$. powieść omówiono w publikacji metodycznej pt. Polskie ksiażki dla dzieci i młodzieży. Katalog historyczny rozumowany, ogłoszonej przez Wydawnictwo Księży Jezuitów w Krakowie. Podkreślono humorystyczny charakter większości akcji ${ }^{14}$.

Pod koniec 1938 r. Walerian Charkiewicz wymienił tę książkę w wileńskim „Słowie” wśród propozycji prezentów gwiazdkowych. Ocenił powieść jako interesujacca lekturę $z$ dużą rolą humoru $\mathrm{w}$ fabule. Zwrócił uwagę na zasadniczą rolę zamku wawelskiego, będącego miejscem akcji ${ }^{15}$. Interesujaca oraz dowcipna opowieść pochwalił też Alfred Jesionowski, pisząc w omówieniu prasowym dla „Kultury” z grudnia 1938 r.: „Wydawnictwo Arcta wydało

${ }^{12}$ K. Siwiec, Antonina Domańska. Dama utalentowana i staroświecka. Rozmowa z Michałem Niezabitowskim, dyrektorem Muzeum Historycznego Miasta Krakowa, „Kraków” 2017, R. XIV, nr 1, s. 57.

13 Por. Katalog informacyjny książek dla dzieci, młodzieży, ludu, sfer szerszych, wychowawców, rodziców, opracowany przez sekcję biblioteczna Towarzystwa imienia Piotra Skargi koła krakowskiego, [t. I], Kraków 1912, s. 51.

${ }_{14}$ Polskie ksiażki dla dzieci i młodzieży. Katalog historyczny rozumowany. Praca zbiorowa, Kraków 1931, s. 77.

15 W. Charkiewicz, Ksiażki dla dzieci i młodzieży na „Gwiazdkę", „Słowo” 1938, R. XVII, nr 353, s. 12. 
ponownie barwną i pełną temperamentu powieść Domańskiej pt. "Paziowie króla Zygmunta". Żywość i różnorodność fabuły zasługuje na szczególne podkreślenie. Szereg zabawnych psot i figli, wyplatanych przez paziów nielubianym dworzanom, a zwłaszcza niewieściemu otoczeniu królowej Bony, zręcznie i artystycznie ze soba połączonych, trzyma czytelnika w zaciekawieniu od pierwszej do ostatniej kartki [...]"16.

Powieści historyczne A. Domańskiej, między nimi Paziowie króla Zygmunta, miały zasadnicze znaczenie w czytelniczym wychowaniu patriotycznym młodzieży w czasach II Rzeczypospolitej obok książek takich pisarzy, jak Józef Ignacy Kraszewski, Henryk Sienkiewicz, Walery Przyborowski, Wacław Gąsiorowski, Wiktor Gomulicki, Deotyma (Jadwiga Łuszczewska), Zuzanna Morawska, Jadwiga Teresa Papi ${ }^{17}$.

W latach siedemdziesiątych XX w. powieść A. Domańskiej przypomniał dziennikarz i autor książek popularnonaukowych Leszek Mazan. W połowie sierpnia 1977 r. zachęcał młodzieżową część czytelników „Przekroju” do poznania Wawelu przez lekturę Paziów króla Zygmunta ${ }^{18}$. W 2004 r. Piotr R. Mazur, omawiając w czasopiśmie „Cywilizacja” Historię żóttej ciżemki, Paziów króla Zygmunta i Krysię Bezimienna A. Domańskiej, pochwalił wymienione powieści za „duży ładunek treści wychowawczych” ${ }^{19}$.

Współczesnym młodym czytelnikom lekturę tekstu sprzed ponad stu lat ułatwia wydanie $z$ opracowaniem, uzupełnione komentarzami na marginesach, ogłoszone w krakowskim wydawnictwie Greg $^{20}$. Zapoznawanie się przez starsze dzieci i młodzież z książ-

16 A. J e si o now s ki, Ksiażki pod choinke, „Kultura” 1938, R. III, nr 51-52, s. 12.

17 J.Z. Białek, Literatura dla dzieci i młodzieży w latach 1918-1939. Zarys monograficzny. Materiały, Warszawa 1979, s. 136.

18 Por. Z profesorem Szabłowskim śladami paziów króla Zygmunta, tych z powieści Antoniny Domańskiej, prowadzi nas po Wawelu - Leszek Mazan, „Przekrój” 1977, R. XXXIII, nr 1688, s. 16 (wydanie z 14 VIII 1977).

19 P.R. Mazur, O historii-dla dzieci i młodzieży, „Cywilizacja. O nauce, moralności, sztuce i religii” 2004, R. III, nr 1, s. 251-252.

${ }^{20}$ A. Domańska, Paziowie króla Zygmunta. Notatki na marginesie. Cytaty, które warto znać. Streszczenie, oprac. B. Włodarczyk, Kraków [2001?], passim. W okresie międzywojennym do samodzielnej lektury pełnego tekstu Paziów króla Zygmunta mogło zachęcać umieszczenie fragmentu powieści w wypisach szkolnych. Por. A. Domańs ka [błędnie wymieniona jako Anna Domańs ka], Dzwon "Zygmunt”, [w:] K. Królińs ki, Polska literatura dla dzieci i młodzieży. Zarys historyczny z wypisami, Lwów 1927, s. 214-218. 
kami uzupełnionymi takim materiałem pomocniczym może im pomagać w przyszłym, bardziej samodzielnym poznawaniu dawnej literatury.

Bardziej popularna powieść A. Domańskiej niż Paziowie króla Zygmunta to Historia żóttej ciżemki (pierwsze wydanie: 1913 r.), często wprowadzana współcześnie przez nauczycieli na listę lektur w piątej lub szóstej klasie ośmioletniej szkoły podstawowej ${ }^{21}$.

Tematem powieści jest historia powstania ołtarza Wita Stwosza, odsłoniętego w kościele Mariackim 15 sierpnia 1489 r. W zakończeniu autorka opisała ceremonię odsłonięcia ołtarza. Uczyła czytelników szacunku dla ludności chłopskiej, zamieszkującej ziemię krakowska. Czyniła to, pokazując jako głównego bohatera chłopca Wawrzka, pochodzącego ze wsi, uczącego się sztuki rzeźbiarskiej w warsztacie Wita Stwosza. Akcja powieściowa obejmuje osiem lat: od ucieczki ponad ośmioletniego Wawrzka $z$ rodzinnej wsi Poręba do uroczystości z sierpnia 1489 r., gdy chłopak miał 18 lat ${ }^{22}$. Pisarka przedstawia plastyczny obraz Krakowa, poznawanego przez dziecięcego bohatera, zadziwionego wielkim miastem, widzianym pierwszy raz w życiu. Wymienia Bramę Floriańska, rynek krakowski (Duży Rynek), kościół Panny Marii (kościół Mariacki), Sukiennice, ulicę Bracką. Ośmioletni chłopiec, zbliżając się do Krakowa, mówi do towarzysza pieszej wędrówki, noszącego imię Stanko: „Rety... a tam, tam, tyle tego... mury strasecne, wiezów tyle... jedna wedle drugiej... strzelaja aze do nieba! Może to nie naprawdę?"23. Pisarka sugestywnie opisuje widowisko $z$ konikiem zwierzynieckim (lajkonikiem). Poza przywołanymi elementami topografii miasta wymienia jako miejsca akcji lub ogólnikowo ulice Floriańską oraz Poselską, kościół i klasztor Bernardynów. Pisze o cmentarzu Świętej Gertrudy, czyli dawnym cmentarzu skazańców, znajdującym się na obszarze części współczesnych Plant, wzdłuż ulicy Świętej Gertrudy od strony Wawelu do ulicy Dominikańskiej.

${ }^{21}$ Przykładowo: http://www.konopnica.edu.pl/index.php/nasza-szkola/wykaz-lektur (dostęp: 6 VII 2018) (wykaz lektur na rok szkolny 2017/2018, dostępny na stronie internetowej Szkoły Podstawowej im. Kardynała Stefana Wyszyńskiego w Konopnicy pod Lublinem); http://www.sp330.waw.pl/strona/dla-rodzicow-i-uczniow/wykaz-lektur.htmla (wykaz lektur na rok szkolny 2018/2019, na stronie internetowej Szkoły Podstawowej nr 330 Z Oddziałami Integracyjnymi im. Nauczycieli Tajnego Nauczania w Warszawie) (dostęp: 26 VII 2019).

${ }^{22}$ Por. A. Domańska, Historia żółtej ciżemki, Wrocław 1995 [dalej: A. Domańs ka, Historia żółtej ciżemki], passim.

${ }^{23}$ Ibidem, s. 54. 
W powieści występuja postacie historyczne związane $z$ miastem, ważne dla polskiej tradycji historyczno-kulturowej: Jan Długosz, będący u schyłku życia, i Wit Stwosz. W fabule biorą udział członkowie królewskiego rodu Jagiellonów: król Kazimierz Jagiellończyk, królowa Elżbieta, królewna Elżbieta Jagiellonka, a także synowie monarchy - królewicze Fryderyk Jagiellończyk, Jan, Aleksander i Zygmunt. Trzy ostatnie spośród wymienionych postaci to późniejsi polscy królowie - następcy Kazimierza Jagiellończyka: Jan Olbracht, Kazimierz Jagiellończyk i Zygmunt I Stary.

Sceneria i obyczajowość krakowska pełnią ważną funkcję w wątku sensacyjnym. Wawrzek ucieka w Krakowie przed fikcyjnym zbójem - Czarnym Rafałem i zostaje tam uratowany przed śmiercia $z$ jego rak. Bohater spotyka Czarnego Rafała pierwszy raz w Krakowie bezpośrednio po obejrzeniu tańca lajkonika. Wcześniej bandyta groził mu podczas wędrówki $z$ Poręby do miasta.

Historia żółtej ciżemki wzbudzała zainteresowanie prasy oraz popularyzatorów czytelnictwa, podobnie jak Paziowie króla Zygmunta. W przywołanym już katalogu informacyjnym z 1912 r. chwalono Historię żółtej ciżemki za „epizody historyczne”, „tło obyczajowe” oraz żywość fabuły. Zalecano ja jako lekturę dla starszych dzieci i młodzieży szkolnej24.

Pierwsze wydanie Historii żółtej ciżemki po drugiej wojnie światowej ukazało się w 1946 r. w Drukarni i Księgarni Świętego Wojciecha w Poznaniu. Wiktor Hahn, oceniajacc wznowienie, niesłusznie skrytykował pisarkę za rozbudowanie wątku sensacyjnego, wprowadzenie grozy. Uważał, że te elementy fabuły sa zbyt drastyczne dla wrażliwych dziecięcych umysłów ${ }^{25}$. Tymczasem, wbrew stwierdzeniu W. Hahna, dodanie do powieści watku z Czarnym Rafałem, poskutkowało zwiększeniem walorów edukacyjnych utworu dzięki ożywieniu fabuły. Wattek sensacyjny wzmocnił wartość wychowawczą ksiażki jako ostrzeżenie przed niebezpieczeństwami mogącymi grozić dzieciom. Pełne grozy wydarzenia rozgrywaja się w topografii krakowskiej.

Inny publicysta, Zygmunt Lichniak, docenił książkę A. Domańskiej za duże zalety literackie oraz edukacyjne. Zwrócił uwagę na

${ }^{24}$ Katalog informacyjny książek dla dzieci..., s. 46.

${ }^{25}$ W. Ha h n, Z literatury dla młodzieży, „Tygodnik Warszawski. Pismo katolickie poświęcone zagadnieniom życia narodowego" 1947 , R. III, nr 11, s. 3. Por. też wydanie z 1946 r.: A. Do mań s ka, Historia żóttej ciżemki. Powieść z czasów panowania Kazimierza Jagiellończyka, z ilustracjami L. Pawlikowskiej, Poznań 1946. 
rzetelność i konkretność realiów historycznych ${ }^{26}$. Piotr R. Mazur trafnie podkreślił w 2004 r., że pisarka kształtuje u dziecięcych odbiorców wrażliwość estetyczną za pomoca opisu powstawania Ołtarza Mariackiego i ostatecznego wyglądu dzieła ${ }^{27}$.

Znana krakowska badaczka literatury dziecięco-młodzieżowej Alicja Baluch pisze $z$ przekonaniem, że Historia żółtej ciżemki dotąd cieszy się zainteresowaniem czytelniczym wśród dzieciei ${ }^{28}$. Wpływa na to częsty wybór nauczycieli tej książki A. Domańskiej jako lektury szkolnej. Jest to publikacja lubiana przez część uczniów, $\mathrm{w}$ przeciwieństwie do wielu innych pozycji $z$ kanonu lekturowego. Dzieje się tak, mimo że autorka raczej nie wykazała się w powieści lekkim piórem i prowadzi narrację dosyć ciężko ${ }^{29}$. W efekcie zdarza się, że książki A. Domańskiej, przeznaczone dla młodszych dzieci, sa trudne nawet dla wyrobionych czytelniczo 11-, 12-latków i staja się bardziej przystępne dopiero, gdy odbiorca ma około 15 lat.

W odbiorze powieści Historia żółtej ciżemki pomaga adaptacja - kolorowy film S. Chęcińskiego z 1961 r. pod tym samym tytułem, o czym świadczą wypowiedzi czytelników dostępne na stronie internetowej lubimyczytac.pl., czyli najbardziej opiniotwórczym polskim portalu czytelniczym. Jeden $z$ dorosłych odbiorców stwierdza przykładowo, że w dzieciństwie wielokrotnie oglądał film, a jako osoba dorosła zapoznał się $z$ fabuła powieściowa, słuchając audiobooka. Zgodnie $z$ jego ocena słuchanie tekstu A. Domańskiej skutkuje doskonałym odbiorem czytelniczym, natomiast samodzielna lektura byłaby trudna $z$ uwagi na archaiczny język. Przekonuje o wartości książki A. Domańskiej w edukacji lokalnej i regionalnej, dowodząc potocznym językiem, charakterystycznym dla wypowiedzi internetowych: ,jest to jedna $z$ lektur obowiązkowych dla krakusów, a dla reszty co kto lubi, nie zaszkodzi”30. Inna osoba wspomina: „Za dzieciaka, kiedy kazano, ciężko się to czytało. Ostatecznie prawie nic nie zapamiętałam [...]"31. Niezależnie od całkowicie lub częścio-

${ }^{26}$ Z. Lichniak, Przeglad literatury dla dzieci i młodzieży, „Przegląd Powszechny" 1949, R. LXVI, t. 227, s. 56.

27 Por. P.R. Mazur, op. cit., s. 251-252.

28 A. Balu ch, Śladem zagubionego bucika. O Antoninie Domańskiej (1853-1917) $w$ stulecie śmierci, „Kraków” 2017, R. XIV, nr 1, s. 55.

${ }^{29}$ Por. A. Domańska, Historia żóttej ciżemki, passim. Por. też A. Domańska, Paziowie króla Zygmunta, oprac. graficzne J.S. Miklaszewski..., passim.

${ }^{30}$ http://lubimyczytac.pl/ksiazka/91959/historia-zoltej-cizemki (dostęp: 30 VII 2019) (wypowiedź internauty o Nicku ad95am, datowana 27 VI 2018 r.).

${ }^{31}$ Ibidem (wypowiedź czytelnika, podpisana Isabel, datowana 11 III 2018 r.). 
wo krytycznych opinii wypowiadanych na lubimyczytac.pl, na tym samym portalu można znaleźć liczne pozytywne, a nawet entuzjastyczne głosy czytelników ${ }^{32}$, co świadczy o przynajmniej częściowej słuszności oceny A. Baluch.

Osoby dyskutujące na lubimyczytac.pl krytykują za język, trudny dla dziecięcych czytelników, także tekst Paziów króla Zygmunta. Jednocześnie polecaja powieść o królewskich paziach młodym czytelnikom jako wartościową lekturę, a część osób wspomina ja $z$ entuzjazmem ${ }^{33}$.

O zainteresowaniu czytelniczym dwoma powieściami A. Domańskiej można się przekonać, przeglądając również inne portale czytelnicze: biblionetka.pl ${ }^{34}$ oraz granice.pl wszystko o literaturze ${ }^{35}$.

32 Ibidem (57 opinii czytelników, najnowsza, datowana 28 V 2019 r.).

${ }^{33}$ http://lubimyczytac.pl/ksiazka/4801961/paziowie-krola-zygmunta (dostęp: 30 VII 2019) (dyskusja internautów, na którą składa się osiem opinii, najnowsza, datowana 25 II 2018 r.). To, że internauci częściej wypowiadaja się nt. Historii żółtej ciżemki niż Paziów króla Zygmunta, wynika $z$ tego, że na popularność pierwszej $z$ wymienionych powieści duży wpływ ma film S. Chęcińskiego, dotąd mający odbiorców. Poza tym to Historia żółtej ciżemki znajduje się w szkolnym kanonie lekturowym, a nie Paziowie króla Zygmunta.

${ }^{34}$ https://www.biblionetka.pl/book.aspx?id=7900\&mode=bookshare\#schowek (dostęp: 30 VII 2019) (dane dotyczace zainteresowania czytelniczego Paziami króla Zygmunta - lista osób pragnących przeczytać lub majacych „w biblioteczce" - schowku na biblionetce tę książkę) (21 osób informuje, że ma Paziów króla Zygmunta w schowku. Na biblionetce nie wszyscy użytkownicy udostępniaja publicznie informacje o zawartości swych „biblioteczek”. Wynika z tego, że w rzeczywistości zainteresowanie powieścią A. Domańskiej wśród osób mających konta na tym portalu może być większe. Poza tym jedna osoba deklaruje, że przeczytała te książkę, a inna zaznaczyła opcję „oddam/wymienię”). Por. też https:/ /www.biblionetka.pl/art.aspx?id=27289 (dostęp: 30 VII 2019) (pozytywna recenzja czytelnicza Historii żółtej ciżemki, podpisana mycha_6, zatytułowana "Dorosłe dzieciństwo" [interpunkcja oryginału], datowana 10 II 2006 r. Dnia 14 IX 2008 r. recenzje mychy_6 uzupełniła siostra_elwisa, dodając komentarz życzliwy dla tej powieści i adaptacji filmowej); https://www.biblionetka.pl/art.aspx?id=877517 (dostęp: 30 VII 2019) (recenzja internautki nt. Historii żółtej ciżemki, podpisana nickiem jaga-b, datowana 31 III 2014 r. Tytuł tej recenzji: Wawrzuś a nowa matura); https://www.biblionetka.pl/book.aspx?id=5096 (dostęp: 30 VII 2019) (wypowiedzi tekstowe trzech internautów powieści Historia żółtej ciżemki, noszace tytuły Spełnione marzenia, cytat z ksiażki [pisownia oryginału], Bardzo takie lubię).

35 https://www.granice.pl/ksiazka/historia-zoltej-cizemki-ksiazka-audio/ 1547 (dostęp: 30 VII 2019) (deklaracje pięciu osób, że chcą się zapoznać z Historia żółtej ciżemki w wersji audio, czyli słuchając audiobooka); https://www. granice.pl/ksiazka/paziowie-krola-zygmunta/185591 (dostęp: 30 VII 2019) (deklaracje pięciu osób, że czytaja, zamierzaja przeczytać lub czytały Paziów króla Zygmunta w edycji drukowanej wydawnictwa Greg, uzupełnionej opracowaniem autorstwa B. Włodarczyk); https://www.granice.pl/ksiazka/paziowie-krola-zygmunta/219454 (dostęp: 30 VII 2019) (deklaracje czterech osób o przeczytaniu, 
Niezależnie od stwierdzenia A. Baluch oraz pozytywnego odbioru powieści Historia żółtej ciżemki przez część czytelników duża grupa odbiorców ma bardzo krytyczny stosunek do tej lektury szkolnej, o czym świadczą komentarze słuchaczy pod nagraniami audiobooków $z$ tekstem tej powieści, dostępnymi na youtube. Między wypowiedziami internautów można też jednak czasem znaleźć pozytywne oceny wysłuchanej książki ${ }^{36}$.

Zainteresowane osoby poznające Historię żółtej ciżemki oraz Paziów króla Zygmunta dzięki lekturze książki drukowanej lub wysłuchanie lektora na audiobooku zapoznaja się z literackim obrazem głównych zabytków związanych $z$ miastem. Dzięki temu mocniej utożsamiaja się z ojczystą tradycja historyczno-kulturową i zarazem patriotyczną.

Mało znany utwór to powieść Kornelii Dobkiewiczowej Haftowane trzewiczki z 1958 r., wydane drugi raz po pięciu latach. Autorka zainspirowała się Historia żółtej ciżemki37. Haftowane trzewiczki, wymienione w tytule i zasadnicze w fabule, to wyrób

chęci przeczytania, względnie posiadaniu we własnym księgozbiorze wydania $\mathrm{Pa}$ ziów króla Zygmunta w edycji wydawnictwa Zielona Sowa); https: / /www.granice. pl/ksiazka/paziowie-krola-zygmunta/220572 (dostęp: 30 VII 2019) (wypowiedzi dwóch osób nt. Paziów króla Zygmunta, wydanych przez Zielona Sowę ["Chcę przeczytać"]); https://www.granice.pl/ksiazka/paziowie-krola-zygmunta-ksiazka-audio-cd-mp3/271153 (dostęp: 30 VII 2019) (jedna bardzo pozytywna ocena tekstowa - wrażenia czytelniczki z wysłuchania Paziów króla Zygmunta na audiobooku w formacie CD MP 3, z Joanną Lissner jako lektorką; słuchaczka zachęca do wysłuchania tej samej wersji uczniów poznających w szkole czasy Jagiellonów na lekcjach historii. Pod tym samym adresem internetowym druga osoba wypowiada deklarację: „Chcę przeczytać”, czyli pragnie posłuchać J. Lissner, czytającej na głos powieść A. Domańskiej); https://www.granice.pl/ksiazka/ paziowie-krola-zygmuntahistoria-zoltej-cizemkikrysia-bezimienna-ksiazka-audio3cd-mp3/271159 (dostęp: 30 VII 2019) (deklaracje czterech osób, że chcą wysłuchać wydania zbiorowego - albumu z trzema płytami CD MP 3 z tekstami Historii żóttej ciżemki, Paziów króla Zygmunta i Krysi Bezimiennej A. Domańskiej).

${ }^{36}$ Por. np. https://www.youtube.com/watch?v=DfhG9OVILlw (dostęp: 1 VIII 2019) (audiobook $z$ tekstem powieści i bardzo krytyczne komentarze internautów, słuchających Historii żółtej ciżemki z obowiązku, jako lektury szkolnej, najnowsze komentarze z 2019 r.); https://www.youtube.com/watch?v=ou4rXlzd4rc (dostęp: 1 VIII 2019); https://www.youtube.com/watch?v=bs5qA_ym1So (dostęp: 1 VIII 2019), https://www.youtube.com/watch?v=xYNyZ8SVQYw (dostęp: 1 VIII 2019), https://www.youtube.com/watch?v=dJOpEo1u34M (dostęp: 1 VIII 2019) (inne publikacje audiobooka $z$ powieścia A. Domańskiej na youtube, uzupełnione komentarzami przez słuchaczy).

${ }_{37}$ Por. S. Frycie, Literatura dla dzieci i młodzieży $w$ latach 1945-1970. Zarys monograficzny. Materiały, t. I (Proza), Warszawa 1978, s. 86; Kr. K. [K. Kuliczkow ska], Historia trzewiczków z safianu, „Nowe Książki” 1958, R. X, nr 17, s. 1062 (recenzja pierwszego wydania Haftowanych trzewiczków). 
kultury materialnej, wykonywany od czasów średniowiecznych przez rzemieślników w Ostrówku na Opolszczyźnie (Śląsk Opolski) ${ }^{38}$. Takim produktem - pozostałością $z$ epoki była też dziecięca ciżemka, o której pisze A. Domańska, rozpoczynając i kończąc narrację w powieści z 1913 r. Akcja Historii żółtej ciżemki toczy się w XV-wiecznym Krakowie, a Haftowanych trzewiczków w XI w. na Opolszczyźnie. Ważna różnica polega na tym, że głównym bohaterem powieści A. Domańskiej jest dziecko, stające się w toku opowieści 18-letnim czeladnikiem, natomiast główny bohater utworu K. Dobkiewiczowej to młody rolnik i rzemieślnik, kupujący tytułowy wyrób jako prezent zaręczynowy ${ }^{39}$. Haftowane trzewiczki sa lektura dla dzieci starszych niż odbiorcy Historii żóttej ciżemki, bo około 13-, 14-letnich. Moga być wykorzystywane głównie w regionalnej opolskiej edukacji czytelniczej i historycznej, przeciwnie niż dzieło A. Domańskiej, będące pozycją o zasięgu ogólnopolskim.

Antonina Domańska opublikowała również mniej znane powieści historyczne o tematyce krakowskiej, równie wartościowe jak jej dwie najpoczytniejsze książki. Najbardziej popularna spośród nich była Krysia Bezimienna z 1914 r. ${ }^{40}$ Kluczowa część akcji toczy się w Krakowie w czasach panowania Henryka Walezego. Autorka kończy fabułę na opisie wesela Anny Jagiellonki i Stefana Batorego, koronowanego na króla polskiego. Tytułowa Krysia, z początku dziecko, później młoda dziewczyna, jest dwórką Anny Jagiellonki ${ }^{41}$. Inspiracją dla pisarki była powieść Zuzanny Morawskiej Na dworze królowej Anny ${ }^{42}$, w której ogromną rolę odgrywa Kraków jako miejsce wydarzeń fikcyjnych i historycznych ${ }^{43}$.

Znacznie słabiej pamiętane książki A. Domańskiej aniżeli Krysia Bezimienna to Hanusia Wierzynkówna. Powiastka z czasów Kazimierza Wielkiego (pierwodruk: 1909 r.) Trzaska i Zbroja. Opowieść

${ }^{38}$ K. Dobki ewiczow a, Haftowane trzewiczki. Opowieść z dawnej przeszłości, Katowice 1963, passim; Autorka [K. Dobkiewiczowa], Posłowie, [w:] K. Dobkiewiczowa, Haftowane trzewiczki..., s. 197.

${ }^{39}$ A. Dom ań s ka, Historia żółtej ciżemki, passim; K. Dobi ewi czow a, Haftowane trzewiczki..., passim.

${ }^{40}$ E.G. [E. Głębicka], op. cit., s. 189; Domańska Antonina (1853-1917)..., s. 444 .

${ }^{41}$ Por. A. Domańska, Krysia Bezimienna, ilustrował A. Uniechowski, Warszawa 1967, passim.

${ }^{42}$ G. Skotnicka, Pozytywistyczne powieści z dziejów narodu dla dzieci i młodzieży, Gdańsk 1974, s. 177-178.

43 Por. Z. Moraw s ka, Na dworze królowej Anny. Powieść na tle historycznym, Warszawa 1912, passim. 
z czasów Kazimierza Wielkiego (1913) oraz Królewska niedola. Powieść z czasów króla Łokietka (1916) ${ }^{44}$. Akcja Hanusi Wierzynkównej toczy się w XIV-wiecznym Krakowie ${ }^{45}$. Na kartach Trzaski i Zbroi pisarka uczyła dzieci szacunku dla podkrakowskiej ludności chłopskiej na przykładzie mieszkańców Łobzowa i Bronowic ${ }^{46}$, czyli terenów stanowiących współcześnie część Krakowa. Rozpoczęła opowieść od wydarzeń w scenerii krakowskiej, wymieniając na pierwszych stronach powieści ulicę Floriańską, Rynek i Kościół Mariacki ${ }^{47}$. Miejsce akcji części Królewskiej niedoli to podkrakowskie przedmieście Rybaki ${ }^{48}$. Większość fabuły jest umiejscowiona w grotach w Ojcowie ${ }^{49}$, czego czytelnik, mający elementarną wiedzę $z$ historii ojczystej, może się domyślić już po tytule.

Omówienie walorów edukacyjnych obrazu Krakowa, zarysowanego przez autorkę w Krysi Bezimiennej, Hanusi Wierzynkównej, a także Trzasce $i$ Zbroi, przekraczałoby ramy tematyczne prezentowanego artykułu, bo utwory te nie maja znaczenia w polskiej tradycji filmowej i teatralnej ${ }^{50}$, w przeciwieństwie do Historii żółtej ciżemki oraz Paziów króla Zygmunta.

Najważniejsza adaptacja powieści A. Domańskiej to film S. Chęcińskiego Historia żółtej ciżemki (1961). Pozycja ta jest jednym z najbardziej znaczących dzieł w historii polskiego kina po $1945 \mathrm{r}$.

W czerwcu 1948 r., czyli ponad dwa lata po odzyskaniu przez Polskę ołtarza Wita Stwosza, wywiezionego z kraju w czasie drugiej wojny światowej przez hitlerowców, w krakowskim dzienniku „Naprzód” ukazała się publikacja Juliana Złotnickiego pt. Dlaczego należałoby sfilmować „Historię żółtej ciżemki”?. „Naprzód” był

${ }^{44}$ E.G. [E. Głębicka], op. cit., s. 189-190; Domańska Antonina (1853-1917)..., s. $443-444$.

45 Por. A. Do mańs ka, Hanusia Wierzynkówna. Powiastka z czasów Kazimierza Wielkiego, ilustrował L. Kowalski, Warszawa 1910; e a d e m, Hanusia Wierzynkówna, [w:] A. Do mańs ka, Trzaska i Zbroja. Hanusia Wierzynkówna. Dwie opowieści z czasów Kazimierza Wielkiego, Warszawa 1961, s. 105-198.

${ }^{46}$ A. Domańska, Trzaska i Zbroja, [w:] ead em, Trzaska i Zbroja. Hanusia Wierzynkówna..., s. 5-104.

47 Ibidem, s. 7-8.

48 A. Do mańska, Królewska niedola. Powieść z czasów króla Łokietka, Poznań 1916, s. 1-24.

49 Ibidem, s. 24 i n.

50 Jedna $z$ wymienionych powieści, Krysia Bezimienna, doczekała się mało znanej wersji radiowej, do której napisała tekst Jadwiga Żylińska. Por. H. Skrobiszewska, Antonina Domańska 1853-1917, [w:] Literatura okresu Młodej Polski.., s. 612. 
organem Polskiej Partii Socjalistycznej. Autor artykułu przekonywał czytelników, głównie osoby prowadzące państwowa politykę kulturalna, o potrzebie wyprodukowania filmowej wersji powieści A. Domańskiej. Zwracał uwagę na wartości poznawcze utworu w dziedzinie historii ojczystej. Pisał o wymowie społecznej Historii żółtej ciżemki, mającej za bohatera chłopskie dziecko, zasłużone przy tworzeniu Ołtarza Mariackiego. Przypominał, że Niemcy kłamliwie dowodzili niemieckości dzieła, stworzonego na polskie zamówienie przez Wita Stwosza $z$ Norymbergi. Argumentował: „Nie będę się rozpisywał o wartościach filmowych [...] powieści, dodam jedynie, że monumentalność wydarzeń, sensacyjność ujęcia i fascynująca fabuła sa podstawowymi i niezaprzeczalnymi elementami dobrego filmu - elementami idealnie rozmieszczonymi na przestrzeni [...] pięknej powieści Antoniny Domańskiej" ${ }^{1}$. Pomysł J. Złotnickiego zyskał poparcie autora artykułu, zamieszczonego jeszcze w tym samym roku w „Echu Krakowa”. Publicysta, podpisany A.S., stwierdził, że propozycja $z$ „Naprzodu” to „Projekt, któremu każdy miłośnik dobrego kina musi przyklasnąć. Oczywiście pod jednym warunkiem: że $z$ dobrej powieści zrobi się dobry, naprawdę dobry film. [...] Taki, który będzie można naprawdę pokazać w kraju i za granica". Autor artykułu skrytykował powojenny polski dorobek filmowy ${ }^{52}$.

Ksiażka została sfilmowana dopiero po kilkunastu latach, w $1961 \mathrm{r}$. Od 1946 r. do 1957 r. nie ukazało się nawet kolejne wznowienie powieści. Wynikało to $z$ przyczyn politycznych ${ }^{53}$. Organy prowadzące politykę wydawniczą w okresie stalinowskim patrzyły niechętnie na ojczystą tradycję religijną, z którą jest ściśle związany ołtarz Wita Stwosza. Odwołanie się przez autorkę do tradycji religijnej przeszkadzało władzom w zrozumieniu wielkiego znaczenia edukacyjno-propagandowego powieści A. Domańskiej po odzyskaniu ołtarza. Głos J. Złotnickiego z „Naprzodu” z czerwca 1948 r. można uznać za jeden $z$ przejawów prób niezależnej publicystyki w prasie,

${ }^{1}$ J. Złotnicki, Dlaczego należałoby sfilmować „Historię żółtej ciżemki”? (publikacja z nagłówkiem Głos w dyskusji), „Naprzód. Organ PPS” 1948, R. LVII, nr 174, s. 6 (numer z 9 VI 1948 r.).

52 A.S., Sprawa filmowania „Żółtej Ciżemki”, „Echo Krakowa” 1948, R. III, nr 187, s. 7.

53 G. Skotnicka, Barwy przeszłości. O powieściach historycznych dla dzieci i młodzieży 1939-1989, Gdańsk 2008, s. 49. Por. też wznowienie Historii żółtej ciżemki z 1957 r.: A. Domań s ka, Historia żółtej ciżemki, ilustrował A. Marczyński, Warszawa 1957 (edycja w wydawnictwie Czytelnik). 
związanej z krajowa Polska Partia Socjalistyczna (PPS). Partię tę zlikwidowano w grudniu 1948 r. Oficjalnie ugrupowanie połaczono z Polską Partia Robotniczą w Polska Zjednoczona Partię Robotniczą. Edycja powieści w 1957 r. i późniejsza produkcja adaptacji filmowej była możliwa dzięki liberalizacji polityki kulturalnej w PRL od $1956 \mathrm{r}$.

Miłośnicy literatury ojczystej oraz filmu, między nimi rodzice dziecięcych czytelników, a także pedagodzy i bibliotekarze mogli śledzić w prasie filmowej wiadomości o pracach realizatorów adaptacji powieści A. Domańskiej. Dnia 22 stycznia 1961 r. w periodyku „Film” ukazał się wywiad z reżyserem S. Chęcińskim. Artysta poinformował Elżbietę Smoleń-Wasilewską, że ma trudności ze znalezieniem dobrego wykonawcy głównej roli dziecięcej ${ }^{54}$. W kolejnym numerze „Filmu” wydrukowano fotoreportaż $z$ castingu ${ }^{55}$. Przygotowywany obraz reklamowano także w reportażu $z$ planu, ogłoszonym na łamach „Filmu” w czerwcu. Przy okazji przedstawiono informację o parze scenografów: Lidii Minticz-Skarżyńskiej i Jerzym Skarżyńskim ${ }^{56}$.

Scenariusz opracowali autorka powieści historycznych dla dzieci Wanda Żółkiewska i dramatopisarz Zdzisław Skowroński. Scenografię i kostiumy zaprojektowali L. i J. Skarżyńscy. Autorem kolorowych zdjęć był Kazimierz Konrad. Muzykę skomponował Zbigniew Turski. Dzieło wyprodukowano w zespole filmowym Iluzjon. W roli Wawrzka zadebiutował z ogromnym sukcesem jedenastoletni Marek Kondrat ${ }^{57}$ ze znanej rodziny aktorskiej, późniejszy bardzo popularny aktor teatralny, kabaretowy i filmowy. Adaptacja

${ }^{54}$ Por. O kłopotach z bohaterem i o Krakowie... pod Łodzia mówi reż. Sylwester Chęcinski, rozmawiała E.S.W. [E. S moleń-W a silews ka) „Film” 1961, nr 4, s. 2.

${ }_{55}$ Por. Realizatorzy $w$ poszukiwaniu bohatera..., zdjęcia I. Małek-Jarosińska, „Film” 1961, R. XVI, nr 5, s. 7 (numer z 29 I 1961 r.).

${ }^{56}$ Por. W łódzkim atelier nowy film dla dzieci. Historia żółtej ciżemki, tekst E. Smoleń-Wasilewska, zdjęcia R. Sumik, „Film” 1961, R. XVI, nr 26, s. 10-11 (numer z 25 VI 1961 r.).

57 http://filmpolski.pl/fp/index.php?film=122186 (dostęp: 29 VII 2019) (opis filmu Historia żółtej ciżemki z 1961 r.); https://www.filmweb.pl/film/Historia+\%C5\%BC\%C3\%B3\%C5\%82tej+ci\%C5\%BCemki-1961-6169 (dostęp: 29 VII 2019) (opis filmu Historia żółtej ciżemki). Por. też H. O poczyńs ka, Filmografia, [w:] Historia filmu polskiego, red. J. Toeplitz, współpraca H. Opoczyńska, S. Ozimek, t. IV (1957-1961), Warszawa 1980, s. 441; W.P. [W. Piątek], Historia źóttej ciżemki, [w:] Leksykon polskich filmów fabularnych, red. J. Słodowski, Warszawa 1997, s. 236; / ha/, Historia żóttej ciżemki, „Filmowy Serwis Prasowy” 1961, nr 16, s. 8 (omówienie filmu); H. Skrobiszewska, op. cit., s. 611-612. Por. też A. Uljas z, Edukacja czy propaganda? Tematyka historyczna w twórczości Wandy 
stanowiła debiut reżyserski S. Chęcińskiego ${ }^{58}$. Premiera odbyła się 28 grudnia 1961 r. ${ }^{59}$ Trzy dni po seansie premierowym dzieło reklamowano w „Filmie” jako „najnowszy film polski”60.

Obraz S. Chęcińskiego otrzymał niezasłużenie bardzo krytyczną recenzję od Joanny Guze. Autorka napisała na temat twórców i efektu ich pracy: „żaden trud i wysiłek nie wyjaśni powstania tworu tak sztucznego, tak pozbawionego wdzięku, rozumnej dydaktyki i inteligentnego stosunku do przeszłości [...]"61. Wśród przyczyn takiej sytuacji widziała niski poziom pierwowzoru literackiego, nazwanego przez nią „lichą”, ckliwą i grafomańska książką. Guze pochwaliła jedynie dekoracje przedstawiające Kraków, wykorzystane w scenach kręconych $\mathrm{w}$ studio filmowym ${ }^{62}$. Historyk polskiego filmu Stanisław Ozimek napisał później o efekcie pracy Skarżyńskich: „Samoistną wartością filmowej Historii żóttej ciżemki stała się scenografia [...], wzorowana na późnogotyckich miniaturach $z$ ich naiwna perspektywa i pełną harmonii gama kolorystyczna" ${ }^{63}$.

Historia żółtej ciżemki S. Chęcińskiego zdobyła uznanie na świecie. W 1962 r. została wyróżniona I nagrodą w kategorii filmów dla młodszych dzieci na XIX Międzynarodowym Festiwalu Filmów dla Dzieci i Młodzieży w Wenecji ${ }^{64}$. W ten sposób autorom scenariusza, realizatorom i wykonawcom udało się zrealizować postulat

Żółkiewskiej, [w:] O etosie ksiażki. Studia z dziejów bibliotek i kultury czytelniczej, red. T. Wilkoń, Katowice 2017, s. 745-746.

58 Por. http://filmpolski.pl/fp/index.php?osoba=11583 (dostęp: 29 VII 2019) (wykaz dorobku S. Chęcińskiego); S. Ozimek, Od wojny w dzień powszedni, [w:] Historia filmu polskiego..., s. 173.

59 http://filmpolski.pl/fp/index.php?film=122186 (dostęp: 29 VII 2019) (opis filmu Historia żóltej ciżemki); https://www.filmweb.pl/film/Historia+\%C5\%BC \%C3\%B3\%C5\%82tej+ci\%C5\%BCemki-1961-6169 (dostęp: 29 VII 2019) (opis filmu Historia żóttej ciżemki).

60 Por. Historia żółtej ciżemki, „Film” 1961, R. XVI, nr 53, s. 16 (numer z 31 XII 1961 r.) (kilka zdjęć z filmu Historia żółtej ciżemki na ostatniej, czwartej stronie okładki, uzupełnionych krótka informacja tekstowa). Por. też Idziemy do kina. Historia żółtej ciżemki, [w:] ibidem, s. 16 (informacja o tym samym filmie, ilustrowana fotografia przedstawiająca Marka Kondrata jako Wawrzka i Andrzeja Szczepkowskiego - Czarnego Rafała).

61 J. Gu ze, Żółta ciżemka, „Film” 1961, R. XVI, nr 51-52, s. 5 (numer z 24 XII 1961 r.).

62 Ibidem.

63 S. Ozimek, op. cit., s. 173.

${ }^{64}$ H. Opoczyńska, op. cit., s. 441; W.P. [W. Piątek], op. cit., s. 237; http:/ / filmpolski.pl/fp/index.php?film=122186 (dostęp: 29 VII 2019) (opis filmu Historia żóttej ciżemki z 1961 r.). 
z prasy krakowskiej z 1948 r., aby powstała wartościowa artystycznie adaptacja filmowa powieści A. Domańskiej, doceniona w Polsce i na świecie. Film był dystrybuowany za granica, np. w 1973 r. trafił do upowszechniania do Meksyku ${ }^{65}$.

Widzowie Historii żóttej ciżemki S. Chęcińskiego sa umiejętnie wprowadzani w XV-wieczny świat czołówka zaprojektowana przez Szymona Kobylińskiego. Plastyk wystylizował ją w większości na księgę rękopiśmienną $z$ końca XV w., względnie inkunabuł, z kolejno otwierającymi się kartami, mający tytuł: Historia żółtej ciżemki. W ten sposób twórcy filmu zachęcają dziecięcych widzów do lektury pierwowzoru literackiego. Reżyser czyni to także w końcowej scenie adaptacji, w której M. Kondrat ogląda ołtarz Wita Stwosza w kościele Mariackim jako współczesne dziecko, trzymajace w ręku książkę A. Domańskiej ${ }^{66}$. Końcową sceną stara się zainteresować dzieci także autentycznym zabytkiem, stanowiącym podstawę fabuły powieści i filmu.

Cały film, nawet sceny rozgrywajacce się $\mathrm{w}$ powieści w plenerach, został nakręcony w studio. Dotyczy to m.in. bram i ulic Krakowa. Na dekoracje składaja się w dużej mierze makiety i malowane na horyzontach pejzaże. Umowność scenografii jest od razu dostrzegana nawet przez młodsze dzieci. Skutkuje to pewnym osłabieniem poczucia grozy scen z Czarnym Rafałem (Andrzej Szczepkowski), co należy uznać za pozytywny efekt. Identyczny charakter ma filmowa sceneria prezentowana w scenach rozgrywających się w miasteczku Myślenice. Kolorowe dekoracje przedstawiajace Kraków sa na tyle estetyczne, że L. i J. Skarżyńscy, autor zdjęć oraz operatorzy wzbudzają u części dzieci zainteresowanie autentyczną sztuką średniowieczna. To samo odnosi się do kostiumów. Studyjny, umowny charakter dekoracji skutkuje oswojeniem się dziecięcych odbiorców z konwencją teatralną. Dzięki niemu realizatorzy wyraźnie ukazują różnicę między fikcją powieściowo-filmową a rzeczywistością historyczną i współczesną. Jest to widoczne przez kontrast końcowej sceny, nakręconej w autentycznym wnętrzu kościoła Mariackiego $z$ początku lat sześćdziesiątych XX w., przed ołtarzem Wita Stwosza, $z$ umowna scenografią do całości filmu ${ }^{67}$. Widzów

65 Film polski na świecie, „Film” 1973, R. XXVIII, nr 8, s. 2.

${ }^{66}$ Historia żółtej ciżemki, film fabularny, scenariusz Z. Skowroński, W. Żółkiewska, Polska 1961, 91‘, DVD, GM Records, Warszawa 2004 (seria: Platynowa Kolekcja Polskiego Kina).

${ }^{67}$ Ibidem. 
dobrze wprowadza w klimat epoki także muzyka $Z$. Turskiego, stylizowana na późnośredniowieczną ${ }^{68}$.

Do ważnych różnic między obrazem Krakowa w powieści i filmie należy to, że w adaptacji filmu S. Chęcińskiego nie występuje Jan Długosz ${ }^{69}$. Najwyraźniej scenarzyści i reżyser nie chcieli obciążać przekazu edukacyjnego zbyt dużą liczbą wiadomości. Dzięki temu uwydatnili zasadniczy, ważny propagandowo temat, jakim była historia powstania i odsłonięcie ołtarza Wita Stwosza.

Gustaw Holoubek, kreując postać mistrza Wita, nie starał się realistycznie udawać postaci historycznej, choć grał w kostiumie z epoki i w charakteryzacji. Postawił sobie za cel uwydatnienie przesłania wychowawczo-dydaktycznego książki i adaptacji filmowej, co udało mu się w retorycznej, przedostatniej scenie w filmie, w której mówi o znaczeniu pracy ludzkich rąk i umysłu dla przyszłych pokoleń, dla których należy pozostawiać po sobie trwałe wartości ${ }^{70}$. Dotyczy to tworzenia spuścizny kultury narodowej i światowej. Młodzi odbiorcy, słuchając słów aktora, mieli się z nia utożsamiać oraz uczyć się szacunku dla niej. Chęciński nie wykorzystał powieściowej sceny $z$ konikiem zwierzynieckim ${ }^{71}$.

Część fabuły została ożywiona na użytek dziecięcych odbiorców przez wprowadzenie do akcji psa towarzyszacego Wawrzusiowi w drodze $z$ Poręby do Krakowa i w Krakowie ${ }^{72}$.

O ile książkę A. Domańskiej można polecać dzieciom w wieku od około 12 lat, o tyle film jest łatwo dostępny percepcji odbiorców mających około dziewięć, dziesięć lat, a nawet nieco młodszych. Wynika to $z$ tego, że artyści filmowi dokonali syntezy fabuły oraz przełożyli trudny język narracji i dialogów powieściowych na obrazy audiowizualne oraz dialogi filmowe.

Historia żółtej ciżemki S. Chęcińskiego cieszyła się dużym powodzeniem w polskich kinach. Film był dostępny w dystrybucji kinowej jeszcze w latach osiemdziesiątych XX w. Stosunkowo często był emitowany w telewizji, w tym po $1989 \mathrm{r}$.

Współczesna recepcja filmu jest ogromnie ułatwiona dzięki edycji na DVD z 2004 r. $^{73}$, dostępnej m.in. w bibliotekach publicz-

68 Ibidem.

69 Ibidem.

70 Ibidem.

71 Ibidem.

72 Ibidem.

${ }^{73}$ Por. przyp. 66. Wcześniej film S. Chęcińskiego był dostępny na kasecie video, wydanej przez Agencję Producentów Filmowych Zespół Video. Por. https://kielce- 
nych $^{74}$ i pedagogicznych ${ }^{75}$. DVD $z$ filmem wzbudza zainteresowanie osób odwiedzających sklepy internetowe ${ }^{76}$.

Nieporównywalnie mniej znana adaptacja audiowizualna niż $\mathrm{Hi}$ storia żóttej ciżemki S. Chęcińskiego to pięcioodcinkowy kolorowy serial telewizyjny G. Warchoła Paziowie z 1989 r., będący przeróbką Paziów króla Zygmunta. Autorem zdjęć jest Tomasz Wert. Scenografię zaprojektował Roman Tarwacki, dekorację wnętrz Teresa Gruber, a kostiumy Renata Własow i Jadwiga Bakanacz. Muzykę skomponował Michał Lorenc. Producent to Centralna Wytwórnia Programów i Filmów Telewizyjnych Poltel. Premiera, czyli pierwsza emisja telewizyjna, miała miejsce 30 stycznia 1990 r. $^{77}$

Akcja serialu toczy się przede wszystkim na Wawelu, tak jak w powieści. W obu opowieściach, literackiej i filmowej, dużą rolę odgrywa przebudowa zamku. Filmowi paziowie są dosyć statyczni

-pbw.sowa.pl/sowacgi.php?KatID=0\&typ=record\&001=TPED17257336 (dostęp: 30 VII 2019) (katalog komputerowy Pedagogicznej Biblioteki Wojewódzkiej [PBW] w Kielcach; opis egzemplarza płyty DVD $z$ filmem, przegranym $z$ kasety video, dostępnej w zbiorach PBW w Kielcach), https://www.lodz-pbw.sowa.pl/sowacgi. php?KatID=0\&typ=record\&001=ELPK11185809 (dostęp: 30 VII 2019) (katalog komputerowy Pedagogicznej Biblioteki Wojewódzkiej im. prof. Tadeusza Kotarbińskiego w Łodzi; opis egzemplarza kasety VHS, dostępnego w łódzkiej bibliotece).

${ }^{74}$ Por. np. http://opac.mbp.lublin.pl/cgi-bin/wspd_cgi.sh/wo2_opbib.p?ID1 $=$ HNNIKHLMQMGNFFGLLRNM $\& 1 \mathrm{n}=$ pl\&RODZAJ $=70 \& I D=28280 \&$ widok $=169 \& N 1$ =W2354584\&N2=1\&N3=169\&N4=70\&srt=t00 (dostęp: 30 VII 2019) (katalog komputerowy Miejskiej Biblioteki Publicznej im. Hieronima Łopacińskiego w Lublinie); https://szukamksiążki.pl/SkNewWeb/record_bibs/2375670 fromSearch=true\& $\max =10 \& a u t o r=\mathrm{Ch} \% c 4 \% 99 \mathrm{ci} \% c 5 \% 84 \mathrm{ski}+$ Sylwester\&sekcja=k\&sekcja=b\&sekcja $=f \&$ sekcja $=w \& s e k c j a=d \& s e k c j a=s \& s e k c j a=i \& s e k c j a=g \& s e k c j a=n \& s e k c j a=e \& o r d e r$ =accuracy (dostęp: 30 VII 2019) (portal internetowy szukamksiążki.pl., zawierajaccy linki do stron licznych bibliotek, w tym małomiejskich i wiejskich; wyszukiwanie informacji o dostępności filmu w zbiorach bibliotek na szukamksiążki.pl - przez wpisanie nazwiska reżysera jako autora).

${ }^{75}$ Por. np. http:/ / 87.246.214.7/ cgi-bin/ makwww.exe?BM=05\&IM=02\&WI=HISTO RIAbxolTEJbCIxEMKI\&NU=01\&DD=2 (dostęp: 30 VII 2019) (opis egzemplarza w katalogu komputerowym Pedagogicznej Biblioteki Wojewódzkiej im. Komisji Edukacji Narodowej w Lublinie); http://katalog.pbw.gda.pl:8080/lib/item?id= chamo:227572\&fromLocationLink=false\&theme=PBWG (dostęp: 30 VII 2019) (opis egzemplarza w katalogu komputerowym Pedagogicznej Biblioteki Wojewódzkiej im. Gdańskiej Macierzy Szkolnej w Gdańsku).

${ }^{76}$ Por. np. https://archiwum.allegro.pl/oferta/wyprzedaz-film-dvd-historia-zoltej-cizemki-i1491364936.html (dostęp: 30 VII 2019) (informacja o sprzedaniu 4 III 2011 r. płyty DVD z Historia żółtej ciżemki).

77 http:/ /filmpolski.pl/fp/index.php?film=126025 (dostęp: 30 VII 2019) (opis serialu telewizyjnego Paziowie z 1989 r.); https://www.filmweb.pl/serial/Paziowie-1989-8585 (dostęp: 30 VII 2019) (opis serialu Paziowie z 1989 r.). 
i mało zabawni w porównaniu z książką. Nieudane role zagrali Halina Rasiakówna i Ryszard Barycz, jako mało majestatyczni królowa Bona i Zygmunt Stary. Znacznie lepsze postacie wykreowali artyści komediowi: Krystyna Sienkiewicz (kucharka Serczykowa) i Edward Dziewoński (Niemiec, doktor Karabatius). Obsadzenie popularnych komików w adaptacji Paziów króla Zygmunta trzeba uznać za uzasadniony pomysł reżysera. Sukces odnieśli także odtwarzający charakterystyczne role: Krystyna Tkacz (dwórka Bony Pappacoda) oraz Wiktor Zborowski (dworski nauczyciel fechtunku). Tkacz gra w języku włoskim, co jest bardzo realistyczna częścią filmowego obrazu Wawelu z czasów panowania Zygmunta Starego i Bony. W serialu w zbyt małym stopniu pokazano autentyczne wawelskie wnętrza i plenery. Dobra stronę produkcji stanowi muzyka M. Lorenca, stylizowana na renesansową, grana częściowo na tradycyjnych instrumentach. Kompozytor przetworzył część partytury elektronicznie, łącząc $w$ ten sposób tradycję muzyczna $z$ gustem widzów telewizyjnych $z$ przełomu lat osiemdziesiątych i dziewięćdziesiątych. Muzyka M. Lorenca dobrze wprowadzała widzów w klimat epoki, zwłaszcza w roli tła do czołówek otwierających odcinki i towarzyszacego zamykającym je końcowym napisom ${ }^{78}$. Po $1990 \mathrm{r}$. serial G. Warchoła był emitowany na kanale telewizyjnym TVP Kultura. Paziowie króla Zygmunta mają też niepamiętaną obecnie adaptację radiowa autorstwa Antoniny Jelicz ${ }^{79}$.

Historia żółtej ciżemki S. Chęcińskiego cieszy się zainteresowaniem miłośników filmu odwiedzających portal filmweb.pl. Film otrzymał 4288 ocen (w sumie - ocena 6,4), a 869 osób informuje o chęci jego obejrzenia ${ }^{80}$. Na forum tej produkcji dyskutowało tylko 37 miłośników sztuki filmowej, ale w dużej rozpiętości czasowej. Co ważne, dyskusja wzbudziła zainteresowanie internautów, bo pod 16 głównymi wypowiedziami znalazło się łącznie 21 komentarzy. Najstarszy głos pochodził z 2001 r., najnowsze zaś z 24 kwietnia

${ }^{78}$ Por. np. https://www.cda.pl/video/137719353 (dostęp: 5 VII 2018) (odcinek 1 serialu Paziowie); https://www.youtube.com/watch?v=V_HlrRaJDKs (dostęp: 30 VII 2019) (odcinek 2 tego serialu); https://www.youtube.com/watch?v=Oc8_uqwy4Gc (dostęp: 30 VII 2019) (odcinek 3); https://www.youtube. com/watch?v=6myBQdodYM4 (dostęp: 30 VII 2019) (odcinek 4) (nagrania emisji odcinków 1-4 serialu Paziowie z polskiego kanału telewizyjnego TVP Kultura).

${ }^{79}$ H. Skrobiszewska, op. cit., s. 612.

80 https://www.filmweb.pl/films / search?q=historia+\% $\% 5 \%$ BC $\%$ C $3 \%$ B3\%C5\%82tej+ci\%C5\%BCemki (dostęp: 30 VII 2019) (wersja skrócona opisu filmu Historia żóttej ciżemki z 1961 r.). 
2017 r. i z 11 marca 2018 r. ${ }^{81}$ Długi czas trwania dyskusji świadczy o możliwości pojawienia się w przyszłości kolejnych wypowiedzi i komentarzy.

Część użytkowników filmwebu ocenia wyżej książkę niż film, a niektórzy wypowiadają odwrotną opinię. Na forum można też znaleźć pogląd, że oba dzieła sa równie wybitne. Jednej osobie spodobała się teatralność wizji, zaprezentowanej przez reżysera. Jeszcze inny internauta wspomina, że w dzieciństwie „dziesiątki razy” oglądał ten film na kasecie video, zawsze $z$ zainteresowaniem ${ }^{82}$.

Głosy oraz wypowiedzi, dostępne na filmweb.pl to tylko część istniejącego zainteresowania adaptacją filmowa powieści A. Domańskiej.

Znacznie mniej osób mających konta na filmweb.pl wspomina Paziów G. Warchoła. Jest to zaledwie jeden internauta (wypowiedź z 1 VI 2015 r.), ale pod jego opinia, zatytułowaną życzliwie: Fajny serial..., umieszczono osiem komentarzy, z czego zdecydowana większość (sześć na osiem) jest całkiem nowa, bo pochodzi z 2018 r. Dwa pozostałe także wpisano całkiem niedawno, w 2014 i 2015 r. Internautom spodobały się stylizowana muzyka, a także „przezabawna” kreacja E. Dziewońskiego i udana rola K. Tkacz ${ }^{83}$. W dyskusji na temat serialu nie ma dużo głosów, ale dostał znacznie więcej ocen $(63$, łączna cena $-6,4)$, a chciałoby go obejrzeć 38 osób $^{84}$.

Powieści A. Domańskiej mają skromna recepcję teatralną. Adaptacje sceniczne opracowano tylko w przypadku Historii żółtej ciżemki. W 1960 r. w Teatrze Klasycznym w Warszawie wystawiono wersję Historii żółtej ciżemki, zatytułowaną Złote ręce. Tekst napisały W. Żółkiewska i Halina Skrobiszewska. Żółkiewska sprawowała wówczas w Teatrze Klasycznym kierownictwo literackie, wspólnie z Z . Skowrońskim. Dyrektorem i kierownikiem artystycznym był Emil Chaberski. Złote ręce wyreżyserował Stanisław Bugajski ${ }^{85}$.

${ }^{81}$ https://www.filmweb.pl/film/Historia+\%C5\%BC\%C3\%B3\%C5\%82tej+ci\%C5\%BCemki-1961-6169/discussion (dostęp: 30 VII 2019) (forum filmu Historia żółtej ciżemki z 1961 r.).

${ }^{82}$ Ibidem (dostęp: 30 VII 2019).

83 https://www.filmweb.pl/serial/Paziowie-1989-8585/discussion/Fajny+ serial....,316792 (dostęp: 30 VII 2019) (forum serialu Paziowie z 1989 r.).

${ }^{84}$ https://www.filmweb.pl/search?q=paziowie\%201989 (dostęp: 30 VII 2019) (wersja skrócona opisu serialu Paziowie z 1989 r.).

85 http://www.e-teatr.pl/pl/realizacje/29598,szczegoly.html (dostęp: 30 VII 2019) (opis realizacji Złotych rak w Teatrze Klasycznym w Warszawie w 1960 r., 
Wawrzusia zagrała dorosła aktorka Danuta Przesmycka. Artystka miała doświadczenie w występowaniu przed dziecięcą widownią. Na początku kariery, w latach 1949-1950, wchodziła w skład zespołu Teatru Dzieci Warszawy. Później, jeszcze przed 1960 r., stosunkowo często grała w sztukach dla dzieci i młodzieży w innych warszawskich teatrach ${ }^{86}$. Inscenizacje reklamowano na mało udanym afiszu. $Z$ grafiki nie wynikało wyraźnie, że sztuka dotyczy ołtarza Wita Stwosza. Prezentowano mało komunikatywny widok rusztowania i jedna $z$ głów wyrzeźbionych na ołtarzu, a w tle ludzka postać, mająca symbolizować mistrza Wita lub Wawrzka, względnie obie te postacie jednocześnie. Symbolikę afisza można rozszyfrować dopiero po jego dokładnym obejrzeniu ${ }^{87}$, podczas gdy istota sztuki plakatu i afisza powinno być szybkie trafianie $z$ przekazem do odbiorcy.

Później przeróbkę teatralną Historii żółtej ciżemki wystawiono tylko trzy razy. Adaptacja nosi tytuł Żółta ciżemka, a napisał ją Stanisław Jastrzębski. Sztukę wystawiono w 1972 r. w Teatrze Rozmaitości w Krakowie (reż. Maria Billiżanka) ${ }^{88}$, w 1985 r. w Teatrze Polskim w Bielsku-Białej-Cieszynie (reż. Jan Sycz) ${ }^{89}$ i w 2006 r. na Scenie Polskiej w Czeskim Cieszynie (reż. Karol Suszka) ${ }^{90}$.

Małe zainteresowanie teatrów adaptacjami scenicznymi Historii żółtej ciżemki wynika $\mathrm{z}$ dużej popularności filmu S. Chęcińskiego. Dyrektorzy teatrów $z$ pewnością wychodzili z przekonania, że rodzice, pedagodzy i dzieci raczej nie zainteresuja się adaptacją

uzupełniony dwoma barwnymi skanami afisza, reklamujacego inscenizację). Por. też H. Skrobiszewska, op. cit., s. 611-612.

${ }^{86}$ http://www.e-teatr.pl/pl/osoby/10612,karierateatr.html\#start (dostęp: 30 VII 2019) (wykaz ról teatralnych D. Przesmyckiej); http://www.e-teatr.pl/pl/osoby /10612,karierazawod.html\#start (dostęp: 30 VII 2019) (opis kariery zawodowej D. Przesmyckiej).

${ }^{87}$ Por. http://www.e-teatr.pl/pl/realizacje/29598,szczegoly.html (dostęp: 30 VII 2019) (dwa barwne skany afisza będącego reklamą inscenizacji Złotych rąk z 1960 r.)

88 http://www.e-teatr.pl/pl/realizacje/18456,szczegoly.html (dostęp: 30 VII 2019) (opis realizacji Żółtej ciżemki z 1972 r., uzupełniony kolorowym skanem afisza).

89 http://www.e-teatr.pl/pl/realizacje/18457,szczegoly.html (dostęp: 30 VII 2019) (opis realizacji Żółtej ciżemki z 1985 r., ilustrowany dwoma czarnobiałymi fotografii ze spektaklu).

90 http://www.e-teatr.pl/pl/realizacje/38305,szczegoly.html (dostęp: 30 VII 2019) (opis realizacji Żółtej ciżemki z 2006 r., uzupełniony barwnym skanem afisza). 
teatralną, mając dostęp do legendarnego filmu, najpierw w kinach i często w telewizji, a potem na kasetach video i płytach DVD.

O walorach patriotycznych twórczości A. Domańskiej dobrze świadczy to, że książki pisarki funkcjonowały w „konspiracyjnym obiegu czytelniczym" w Polsce pod okupacja hitlerowska, podobnie jak np. Krzyżacy Henryka Sienkiewicza i powieści Walerego Przyborowskiego ${ }^{91}$ po wprowadzaniu przez okupanta zakazu ich rozpowszechniania ${ }^{92}$.

Powieści autorki moga być przydatne także we współczesnej edukacji historyczno-patriotycznej ${ }^{93}$, ogólnopolskiej i regionalnej krakowskiej, prowadzonej w szkołach oraz przez biblioteki publiczne. Jako ważna pomoc należy wykorzystywać film S. Chęcińskiego według Historii żółtej ciżemki, dostępny na płytach DVD. Potrzebna jest nowa edycja płytowa dzieła z 1961 r., aby biblioteki publiczne i pedagogiczne oraz osoby prywatne mogły uzupełnić o nia zbiory multimedialne.

Opowieści historyczne A. Domańskiej zajmują ważne miejsce w polskiej tradycji literackiej i wydawniczej. Książce Historia żóttej ciżemki dorównała adaptacja S. Chęcińskiego, stanowiąc jedną z najważniejszych pozycji w dziejach ojczystego filmu. Współcześni odbiorcy maja kontakt $z$ patriotycznym obrazem Krakowa i jego zabytków, stworzonym przez pisarkę, za pośrednictwem ksiażek drukowanych oraz nowych mediów - e-booków, cyfrowych audiobooków, Internetu jako metamedium i płyt DVD.

${ }^{91}$ G. Skotnicka, Barwy przeszłości..., s. 19.

92 S. Pazy ra, Z dziejów książki polskiej w czasie drugiej wojny światowej, Warszawa 1970 , s. $52-53$.

${ }^{93}$ Badaczka, która zwróciła uwagę na ponadczasowość wartości edukacyjnych powieści A. Domańskiej, jest Ewelina Niemiec. Por. E. Niemiec, Bohaterowie wybranych utworów Antoniny Domańskiej jako inspiracja dla nowoczesnego patriotyzmu, „Guliwer” 2018, R. XXVIII, nr 3, s. 7-11. 


\section{Bibliografia}

\section{Ź RÓDEA DRUKOWANE}

/ ha/, Historia żółtej ciżemki, „Filmowy Serwis Prasowy” 1961, R. VII, nr 16, s. 8-12 (omówienie filmu).

A.S., Sprawa filmowania „Żóttej Ciżemki”, „Echo Krakowa” 1948, R. III, nr 187, s. 7.

Antonina Domańska, „Kobieta Polska” 1917, R. II, nr 3, s. 8 (notatka pośmiertna o A. Domańskiej).

Arct S., Okruchy wspomnień, Warszawa 1962.

Autorka [K. Dobkiewiczowa], Posłowie, [w:] K. Dobkiewiczowa, Haftowane trzewiczki. Opowieść z dawnej przeszłości, Katowice 1963, s. 196-199.

Charkiewicz W., Książki dla dzieci i młodzieży na „Gwiazdkę, „Słowo” 1938, R. XVII, nr 353, s. 10, 12.

Dobkiewiczowa K., Haftowane trzewiczki. Opowieść z dawnej przeszłości, Katowice 1963.

Domańska A. [błędnie wymieniona jako Anna Domańska], Dzwon „Zygmunt”, [w:] K. Króliński, Polska literatura dla dzieci i młodzieży. Zarys historyczny z wypisami, Lwów 1927, s. 214-218.

Domańska A., Hanusia Wierzynkówna, [w:] A. Domańska, Trzaska i Zbroja. Hanusia Wierzynkówna. Dwie opowieści z czasów Kazimierza Wielkiego, Warszawa 1961, s. 105-198.

Domańska A., Hanusia Wierzynkówna. Powiastka z czasów Kazimierza Wielkiego, ilustrował L. Kowalski, Warszawa 1910.

Domańska A., Historia żółtej ciżemki, Wrocław 1995.

Domańska A., Historia żółtej ciżemki, ilustrował A. Marczyński, Warszawa 1957.

Domańska A., Historia żółtej ciżemki. Powieść z czasów panowania Kazimierza Jagiellończyka, z ilustracjami L. Pawlikowskiej, Poznań 1946.

Domańska A., Królewska niedola. Powieść z czasów króla Łokietka, Poznań 1916.

Domańska A., Krysia Bezimienna, ilustrował A. Uniechowski, Warszawa 1967.

Domańska A., Paziowie króla Zygmunta, oprac. graficzne J.S. Miklaszewski, Warszawa 1962.

Domańska A., Paziowie króla Zygmunta. Notatki na marginesie. Cytaty, które warto znać. Streszczenie, oprac. B. Włodarczyk, Kraków [2001?].

Domańska A., Trzaska i Zbroja, [w:] A. Domańska, Trzaska i Zbroja. Hanusia Wierzynkówna. Dwie opowieści z czasów Kazimierza Wielkiego, Warszawa 1961, s. 5-104.

Film polski na świecie, „Film” 1973, R. XXVIII, nr 8, s. 2.

Guze J., Żółta ciżemka, „Film” 1961, R. XVI nr 51-52, s. 5.

Hahn W., Z literatury dla młodzieży, „Tygodnik Warszawski” 1947, R. III, nr 11, s. 3.

Historia żółtej ciżemki, „Film” 1961, R. XVI, nr 53, s. 16. 
Idziemy do kina. Historia żółtej ciżemki, „Film” 1961, R.XVI, nr 53, s. 16.

Jesionowski A., Książki pod choinkę, „Kultura” 1938, R. III, nr 51-52, s. 12.

Katalog informacyjny ksiażek dla dzieci, młodzieży, ludu, sfer szerszych, wychowawców, rodziców, opracowany przez sekcje biblioteczna Towarzystwa imienia Piotra Skargi koła krakowskiego, [t. I], Kraków 1912.

Kr. K. [K. Kuliczkowska], Historia trzewiczków z safianu, „Nowe Książki” 1958, R. X, nr 17, s. 1062 .

Lichniak Z., Przegląd literatury dla dzieci i młodzieży, „Przegląd Powszechny” 1949, R. LXVI, t. 227, s. 54-56.

Mazur P.R., O historii-dla dzieci i młodzieży, „Cywilizacja. O nauce, moralności, sztuce i religii” 2004, R. III, nr 1, s. 250-252.

Morawska Z., Na dworze królowej Anny. Powieść na tle historycznym, Warszawa 1912.

O kłopotach z bohaterem i o Krakowie... pod Łodzia mówi reż. Sylwester Chęciński, rozmawiała E.S.W. [E. Smoleń-Wasilewska) „Film” 1961, R. XVI, nr 4, s. 2.

Polskie ksiażki dla dzieci i młodzieży. Katalog historyczny rozumowany. Praca zbiorowa, Kraków 1931.

Realizatorzy w poszukiwaniu bohatera..., zdjęcia I. Małek-Jarosińska, „Film” 1961, R. XVI, nr 5, s. 7.

Siwiec K., Antonina Domańska. Dama utalentowana i staroświecka. Rozmowa $z$ Michałem Niezabitowskim, dyrektorem Muzeum Historycznego Miasta Krakowa, „Kraków” 2017, R. XIV, nr 1, s. 57-58.

$W$ łódzkim atelier nowy film dla dzieci. Historia żółtej ciżemki, tekst E. Smoleń-Wasilewska, zdjęcia R. Sumik, „Film” 1961, R. XVI, nr 26, s. 10-11.

Złotnicki J., Dlaczego należałoby sfilmować „Historię żółtej ciżemki”? (publikacja $z$ nagłówkiem Głos $w$ dyskusji), „Naprzód” 1948, R. LVII, nr 174, s. 6.

$Z$ profesorem Szabłowskim śladami paziów króla Zygmunta, tych z powieści Antoniny Domańskiej, prowadzi nas po Wawelu - Leszek Mazan, „Przekrój” 1977, R. XXXIII, nr 1688, s. 16.

\section{Źródea AUdiowizualne}

Historia żółtej ciżemki, film fabularny, scenariusz Z. Skowroński, W. Żółkiewska, Polska 1961, 91‘, DVD, GM Records, Warszawa 2004 (seria: Platynowa Kolekcja Polskiego Kina).

\section{OpRacowania}

as [T. Sinko], Poetka lalek i dzieci. Śp. Antonina Domańska, „Czas” 1917, R. LXX, nr 53, s. 1-2.

Baluch A., Śladem zagubionego bucika. O Antoninie Domańskiej (1853-1917) $w$ stulecie śmierci, „Kraków” 2017, R. XIV, nr 1, s. 54-56.

Białek J.Z., Literatura dla dzieci i młodzieży w latach 1918-1939. Zarys monograficzny. Materiały, Warszawa 1979. 
Ciechanowska Z., Domańska z Kremerów Antonina (1853-1917), [w:] Polski słownik biograficzny, t. V, z. 1, Kraków 1939, s. 299.

Domańska Antonina (1853-1917), [w:] Słownik współczesnych pisarzy polskich, red. E. Korzeniewska, t. I (a-i), Warszawa 1963, s. 443-445.

Dziedzic S., Pani radczyni - Antonina Domańska, „Dialog Dwóch Kultur” 2017, R. XII, z. 1, s. 273-283.

E.G. [E. Głębicka], Domańska Antonina 1853-1917, [w:] Współcześni polscy pisarze i badacze literatury. Słownik biobliograficzny, red. J. Czachowska, A. Szalagan, t. II $(C-F)$, Warszawa 1994, s. 188-190.

Frycie S., Literatura dla dzieci i młodzieży w latach 1945-1970. Zarys monograficzny. Materiały, t. I (Proza), Warszawa 1978.

Kątny M., Antonina Domańska. Propagator przeszłości narodowej, „Studia Słowianoznawcze" 2006, R. VI, s. 21-40.

KK [K. Kuliczkowska], Domańska Antonina ur. IX 1853 w Kamieńcu, zm. 26 I 1917 w Krakowie, [w:] Nowy słownik literatury dla dzieci i młodzieży. Pisarze. Ksiązki. Serie. Ilustratorzy. Przeglad bibliograficzny, Warszawa 1979, s. 140-141.

Kosowska E., Porady (?) radczyni. O powieściach historycznych Antoniny Domańskiej, „Guliwer” 2012, R. XXII, nr 1, s. 41-45.

Kuliczkowska K., Literatura dla dzieci i młodzieży, [w:] Literatura okresu Młodej Polski, t. III, red. K. Wyka, A. Hutnikiewicz, M. Puchalska, Kraków 1973, s. 576-581.

MZS [M. Ziółkowska-Sobecka], Domańska Antonina, [w:] S. Frycie, M. Ziółkowska-Sobecka, Leksykon literatury dla dzieci i młodzieży, Piotrków Trybunalski 1999, s. 77-78.

Niemiec E., Bohaterowie wybranych utworów Antoniny Domańskiej jako inspiracja dla nowoczesnego patriotyzmu, „Guliwer” 2018, R. XXVIII, nr 3, s. 7-11.

Opoczyńska H., Filmografia, [w:] Historia filmu polskiego, red. J. Toeplitz, współpraca H. Opoczyńska, S. Ozimek, t. IV (1957-1961), Warszawa 1980, s. 423-466.

Ozimek S., Od wojny $w$ dzień powszedni, [w:] Historia filmu polskiego, red. J. Toeplitz, współpraca H. Opoczyńska, S. Ozimek, t. IV (1957-1961), Warszawa 1980, s. 129-198.

Pazyra S., Z dziejów ksiażki polskiej w czasie drugiej wojny światowej, Warszawa 1970.

Skotnicka G., Barwy przeszłości. O powieściach historycznych dla dzieci i młodzieży 1939-1989, Gdańsk 2008.

Skotnicka G., Dzieje piórem malowane. O powieściach historycznych dla dzieci $i$ młodzieży z okresu Młodej Polski $i$ dwudziestolecia międzywojennego, Gdańsk 1987.

Skotnicka G., Pozytywistyczne powieści z dziejów narodu dla dzieci i młodzieży, Gdańsk 1974.

Skotnicka G., Tradycje narodowo-kulturowe w polskiej powieści historycznej dla dzieci i młodzieży, [w:] Tradycje narodowo-kulturowe w literaturze dla dzieci i młodzieży. Materiały z sesji Jachranka, 30 XI- 2 XII 1994 r., Warszawa 1996, s. 41-50. 
Skrobiszewska H., Antonina Domańska 1853-1917, [w:] Literatura okresu Młodej Polski, t. III, red. K. Wyka, A. Hutnikiewicz, M. Puchalska, Kraków 1973, s. 611-612.

Uljasz A., Edukacja czy propaganda? Tematyka historyczna $w$ twórczości Wandy Żółkiewskiej, [w:] O etosie książki. Studia z dziejów bibliotek i kultury czytelniczej, red. T. Wilkoń, Katowice 2017, s. 743-756.

W.P. [W. Piątek], Historia żółtej ciżemki, [w:] Leksykon polskich filmów fabularnych, red. J. Słodowski, Warszawa 1997, s. 236-237.

\section{NetOGRAFiA}

Forum filmu S. Chęcińskiego Historia żóttej ciżemki z 1961 r. na portalu internetowym filmweb.pl, https://www.filmweb.pl/film/Historia+\%C5\%BC\%C3\% B3\%C5\%82tej+ci\%C5\%BCemki-1961-6169/discussion (dostęp: 30 VII 2019).

Forum serialu telewizyjnego G. Warchoła Paziowie z 1989 r. na portalu internetowym filmweb.pl, https://www.filmweb.pl/serial/Paziowie-1989-8585/discussion/Fajny+serial....,316792 (dostęp: 30 VII 2019).

Opis kariery zawodowej aktorki D. Przesmyckiej, http://www.e-teatr.pl/pl/osoby / 10612,karierazawod.html\#start (dostęp: 30 VII 2019).

Opis kasety VHS z filmem S. Chęcińskiego Historia żółtej ciżemki z 1961 r. w bibliotecznym katalogu komputerowym, https://www.lodz-pbw.sowa.pl/sowacgi. php?KatID=0\&typ=record\&001=ELPK1 1185809 (dostęp: 30 VII 2019) (katalog komputerowy Pedagogicznej Biblioteki Wojewódzkiej im. prof. Tadeusza Kotarbińskiego w Łodzi).

Opis realizacji sztuki teatralnej H. Skrobiszewskiej i W. Żółkiewskiej Złote ręce według Historii żółtej ciżemki A. Domańskiej (Teatr Klasyczny w Warszawie, 1960 r.) na portalu internetowym teatr.pl, http://www.e-teatr.pl/pl/realizacje /29598, szczegoly.html (dostęp: 30 VII 2019).

Opis serialu telewizyjnego G. Warchoła Paziowie z 1989 r. na portalu internetowym filmpolski.pl, http://filmpolski.pl/fp/index.php?film=126025 (dostęp: 30 VII 2019).

Opis serialu telewizyjnego G. Warchoła Paziowie z 1989 r. na portalu internetowym filmweb.pl, https://www.filmweb.pl/serial/Paziowie-1989-8585 (dostęp: 30 VII 2019).

Opis serialu telewizyjnego G. Warchoła Paziowie z 1989 r. na portalu internetowym filmweb.pl - wersja skrócona, https://www.filmweb.pl/search?q=paziowie\%201989 (dostęp: 30 VII 2019).

Opisy filmu S. Chęcińskiego Historia żółtej ciżemki z 1961 r. na portalu internetowym filmpolski.pl, http://filmpolski.pl/fp/index.php?film=122186 (dostęp: 29 VII 2019); https://www.filmweb.pl/film/Historia+\%C5\%BC\%C3\%B3\%C5\%82tej +ci\%C5\%BCemki-1961-61 (dostęp: 29 VII 2019); https://www.filmweb.pl/ films / search?q=historia+\%C5\%BC\%C3\%B3\%C5\%82tej+ci\%C5\%BCemki (dostęp: 30 VII 2019) (wersja skrócona).

Opisy płyty DVD z filmem S. Chęcińskiego Historia żółtej ciżemki z 1961 r. w bibliotecznych katalogach komputerowych, http://opac.mbp.lublin.pl/cgi-bin/ 
wspd_cgi.sh/wo2_opbib.p?ID $1=$ HNNIKHLMQMGNFFGLLRNM $\& 1 n=$ p1\&RODZAJ $=70 \& I D=28280 \& w i d o k=169 \& N 1=W 2354584 \& N 2=1 \& N 3=169 \& N 4=7$ 0\&srt=t00 (dostęp: 30 VII 2019) (katalog komputerowy Miejskiej Biblioteki Publicznej im. Hieronima Łopacińskiego w Lublinie); http://87.246.214.7/ cgibin / makwww.exe?BM=05\&IM=02\&WI=HISTORIAbxolTEJbCIxEMKI\&NU$=01 \& \mathrm{DD}=2$ (dostęp: 30 VII 2019) (katalog komputerowy Pedagogicznej Biblioteki Wojewódzkiej im. Komisji Edukacji Narodowej w Lublinie); http:/ / katalog. pbw.gda.pl:8080/lib/item?id=chamo:227572\&fromLocationLink=false\&theme=PBWG (dostęp: 30 VII 2019) (katalog komputerowy Pedagogicznej Biblioteki Wojewódzkiej im. Gdańskiej Macierzy Szkolnej w Gdańsku); https:// kielce-pbw. sowa.pl/sowacgi.php?KatID=0\&typ=record\&001=TPED17257336 (dostęp: 30 VII 2019) (katalog komputerowy Pedagogicznej Biblioteki Wojewódzkiej w Kielcach).

Opisy realizacji teatralnych sztuki S. Jastrzębskiego Żółta ciżemka według Historii żółtej ciżemki A. Domańskiej na portalu internetowym e-teatr.pl: http://www. e-teatr.pl/pl/realizacje/18456,szczegoly.html (dostęp: 30 VII 2019) (Teatr Rozmaitości w Krakowie, 1972 r.), http://www.e-teatr.pl/pl/realizacje/18457, szczegoly.html (dostęp: 30 VII 2019) (Teatr Polski w Bielsku-Białej-Cieszynie, 1985 r.), http://www.e-teatr.pl/pl/realizacje/38305, szczegoly.html (dostęp: 30 VII 2019) (Scena Polska w Czeskim Cieszynie - 2006 r.).

Portal internetowy allegro.pl, https://archiwum.allegro.pl/oferta/wyprzedaz-film-dvd-historia-zoltej-cizemki-i1491364936.html (dostęp: 30 VII 2019) (informacja o sprzedaniu 4 III 2011 płyty DVD z Historia żółtej ciżemki).

Portal internetowy biblionetka.pl - wypowiedzi internautów nt. powieści A. Domańskiej Historia żółtej ciżemki, https: / / www.biblionetka.pl/art.aspx?id=27289 (dostepp: 30 VII 2019); https://www.biblionetka.pl/art.aspx?id=877517 (dostęp: 30 VII 2019); https://www.biblionetka.pl/book.aspx?id=5096 (dostęp: 30 VII 2019); wypowiedzi internautów nt. powieści A. Domańskiej Paziowie króla Zygmunta, https:/ /www.biblionetka.pl/book.aspx?id=7900\&mode=bookshare\#schowek (dostęp: 30 VII 2019).

Portal internetowy cda.pl - nagranie odcinka 1 serialu telewizyjnego G. Warchoła Paziowie z 1989 r. $z$ emisji na kanale telewizyjnym TVP Kultura, https://www. cda.pl/video/137719353 (dostęp: 5 VII 2018).

Portal internetowy granice.pl - Wszystko o literaturze - wypowiedzi internautów o powieści A. Domańskiej Historia żółtej ciżemki, https://www.granice. pl/ksiazka/historia-zoltej-cizemki-ksiazka-audio/1547 (dostęp: 30 VII 2019); wypowiedzi internautów na temat powieści A. Domańskiej Paziowie króla Zygmunta, https://www.granice.pl/ksiazka/paziowie-krola-zygmunta/185591 (dostęp: 30 VII 2019), https://www.granice.pl/ksiazka/paziowie-krola-zygmunta/219454 (dostęp: 30 VII 2019), https://www.granice.pl/ksiazka/paziowie-krola-zygmunta-ksiazka-audio-cd-mp3/271153 (dostęp: 30 VII 2019).

Portal internetowy lubimyczytać.pl - wypowiedzi internautów na temat powieści A. Domańskiej Historia żółtej ciżemki, http://lubimyczytac.pl/ksiazka/91959/ historia-zoltej-cizemki (dostęp: 30 VII 2019); wypowiedzi internautów nt. powieści A. Domańskiej Paziowie króla Zygmunta, http://lubimyczytac.pl/ ksiazka/4801961/paziowie-krola-zygmunta (dostęp: 30 VII 2019). 
Portal internetowy szukamksiążki.https://www.granice.pl/ksiazka/paziowie-krolazygmuntahistoria-zoltej-cizemkikrysia-bezimienna-ksiazka-audio-3cdmp3/271159pl - opisy płyty DVD z filmem S. Chęcińskiego Historia żółtej ciżemki w bibliotecznych katalogach komputerowych https://szukamksiążki.pl/SkNewWeb/record_bibs / 2375670?fromSearch=true\&max=10\&auto$\mathrm{r}=\mathrm{Ch} \% \mathrm{c} 4 \% 99 \mathrm{ci} \% \mathrm{c5} \% 84 \mathrm{ski}+$ Sylwester\&sekcja $=\mathrm{k} \&$ sekcja $=\mathrm{b} \& \mathrm{sekcja}=\mathrm{f} \& \mathrm{sek}$ cja $=$ $w \& s e k c j a=d \& s e k c j a=s \& s e k c j a=i \& s e k c j a=g \& s e k c j a=n \& s e k c j a=e \& o r d e r=a c c u-$ racy (dostęp: 30 VII 2019).

Portal internetowy youtube.pl - nagrania audiobooków $z$ tekstem powieści A. Domańskiej Historia żółtej ciżemki, uzupełnione komentarzami przez internautów, https: / /www.youtube.com/watch?v=DfhG9OVILlw (dostęp: 1 VIII 2019); https://www.youtube.com/watch?v=ou4rXlzd4rc (dostęp: 1 VIII 2019); https://www.youtube.com/watch?v=bs5qA_ym1So (dostęp: 1 VIII 2019); https://www.youtube.com/watch?v=xYNyZ8SVQYw (dostęp: 1 VIII 2019); https://www.youtube.com/watch?v=dJ0pEo1u34M (dostęp: 1 VIII 2019).

Portal internetowy youtube.pl - nagrania emisji odcinków 2-4 serialu G. Warchoła Paziowie z 1989 r. polskiego kanału telewizyjnego TVP Kultura, https:/ / www. cda.pl/video/137719353 (dostęp: 5VIII 2018) (odcinek 1); https:/ / www.youtube. com/watch?v=V_HlrRaJDKs (dostęp: 30 VII 2019) (odcinek 2); https://www. youtube.com/watch?v=Oc8_uqwy4Gc (dostęp: 30 VII 2019) (odcinek 3); https://www.youtube.com/watch?v=6myBQdodYM4 (dostęp: 30 VII 2019) (odcinek 4).

Wykaz dorobku S. Chęcińskiego, opublikowany na portalu filmpolski.pl, http:// filmpolski.pl/fp/index.php?osoba=11583 (dostęp: 29 VII 2019).

Wykaz lektur na rok szkolny 2017/2018, dostępny na www Szkoły Podstawowej im. Kardynała Stefana Wyszyńskiego w Konopnicy pod Lublinem, http:/ /www. konopnica.edu.pl/index.php/nasza-szkola/wykaz-lektur (dostęp: 6 VII 2018).

Wykaz lektur na rok szkolny 2018/2019, dostępny na www Szkoły Podstawowej nr 330 Z Oddziałami Integracyjnymi im. Nauczycieli Tajnego Nauczania w Warszawie, http://www.sp330.waw.pl/strona/dla-rodzicow-i-uczniow/wykazlektur.html (dostęp: 26 VII 2019).

Wykaz ról teatralnych aktorki D. Przesmyckiej, http://www.e-teatr.pl/pl/osoby / 10612,karierateatr.html\#start (dostęp: 30 VII 2019).

ADRIAN ULJASZ

UNIVERSITY OD RZESZÓW

\section{Historical novels of Antonina Domańska in literary, audiovisual, digital and theatrical forms}

$\mathrm{T}$ he Krakow writer Antonina Domańska (1853-1917) occupies a permanent place in the Polish cultural tradition as an author of literary works for children and youth, mainly historical novels. Her best known books are Paziowie króla 
Zygmunta (1910) and Historia żóttej ciżemki (1913). These novels were adapted, the first as Sylwester Chęciński's film (1961) and the second as television series of Grzegorz Warchol (1989). Polish theaters also staged modifications to the Historia żóttej ciżemki. The subject of the article is the image of Krakow in these novels as a key element of Domańska's historical and patriotic education. The second research issue is the film, television and theatre reception of the writer's two works.

Keywords: Antonina Domańska (1853-1917), historical novel for children, history of Polish film after 1945; history of Polish theater after 1945. 